\title{
Notes on Taxonomy and Distribution of Murdannia Striatipetala Faden (Commelinaceae) in Pondicherry, India
}

\author{
Vijayakumar Dhaarani, Manokaran Parthipan, Arumugam Rajendran* \\ Phytodiversity Research Laboratory, Department of Botany, School of Life Sciences, Bharathiar University, Coimbatore, Tamil Nadu, India
}

\author{
Email address: \\ slvmlingam@gmail.com (A. Rajendran) \\ ${ }^{*}$ Corresponding author
}

\section{To cite this article:}

Vijayakumar Dhaarani, Manokaran Parthipan, Arumugam Rajendran. Notes on Taxonomy and Distribution of Murdannia Striatipetala Faden (Commelinaceae) in Pondicherry, India. American Journal of BioScience. Vol. 5, No. 1, 2017, pp. 1-3. doi: 10.11648/j.ajbio.20170501.11

Received: January 3, 2017; Accepted: March 1, 2017; Published: March 21, 2017

\begin{abstract}
Murdannia striatipetala Faden, a native species to Sri lanka hither to recorded only from Tamil Nadu is reported here for the first time from coastal region of Karaikal, Pondicherry, India. The new record of this species is presented here with brief botanical description, illustration and relevant data for easy identification.
\end{abstract}

Keywords: Murdannia, Commelinaceae, Coastal Regions, New Record, Pondicherry

\section{Introduction}

As defined by [1], family comprises 50 genera and about 700 species, widely distributed in tropical and sub-tropical regions of the world. Peninsular India and the foothills of Himalayas to Thailand and Southwestern China is major center of diversity for Commelinaceae [2]. Murdannia striatipetala is a dazzling but little known species of southern India. It was described by [3] based on his earlier collection from Jaffna, Sri Lanka, in 1977. Commelinaceae is commonly known as the 'Spiderwort family' and was created by [4] with Commelina as the type genus. [5] has reported 710 species under 41 genera, [6] has reported 600 species under 40 genera which are distributed worldwide, mainly in tropical to warm temperate regions. Earlier, [7] has recorded 22 species in Flora of British India, [8] treated 15 species in Flora of Presidency of Bombay, [9] treated 19 species of Murdannia especially from South India in Gamble's Flora of The Presidency of Madras. In India, this family is represented by about 90 species within 14 genera [7, 8]. The genus is represented with 26 species, of which 23 occurs in South India [10].

Murdannia is a pantropical genus with ca. 50 species and occurs in a variety of open mesic or occasionally aquatic habitats, rarely in forests [11]. In India, the genus is represented 27 species by [12]; subsequently Murdannia Royle [13], have been added to Indian flora, bringing the total number into ca. 28 species. [14] have reported earlier from Tamil Nadu (Red hills), previous reports and collections indicate that this species occurs only in Tamil Nadu, not in Pondicherry [15]. Therefore, the present collection from the coastal regions of Karaikal forms a new record for Pondicherry.

Murdannia striatipetala is closely related to $M$. spirata, but characters such as definite base, narrow leaves, dark-veined petals, and short appressed hairs on the stamen and filaments had made it distinct. In addition, restrictedhabitat of $M$. striatipetala against widespread habitat of $M$. spirata was notable. Inflorescence of $M$. dimorphoides closely resembles $M$. striatipetala. Contrasting dark-veined petals are also characteristic of Murdannia spirata (L.) Bruckner var. parviflora Faden (endemic to Sri Lanka, Faden 2001), but it differs from $M$. striatipetala by characters like indefinite base, flowers c. $10-12 \mathrm{~mm}$ wide, stamen dimorphism. The distribution of this species was reported to be northern Sri Lanka and southern India, which Faden widened on the basis of earlier collections from India.

Since a complete description for this species is not available in any of the Pondicherry floras or taxonomic accounts, a detailed description along with colour photoplate is provided to facilitate accurate identification.

\section{Materials and Methods}

Study area 
Karaikal coast covers an area of $17.28 \mathrm{~km}$. It forms the Union territory of Pondicherry. It lies in $10.9254^{\circ} \mathrm{N}$ latitude and $79.83800^{\circ} \mathrm{E}$ longitude. The study area experiences tropical maritime climate. The average rainfall is $26 \mathrm{~cm}$. December and January are the coolest month with maximum of about $28^{\circ} \mathrm{C}$ and minimum $23^{\circ} \mathrm{C}$. Minimum temperature is as low as $16^{\circ} \mathrm{C}$. The diurnal ranges of temperature are generally small throughout the year being highest about $10^{\circ} \mathrm{C}$, in May and June, and the least about $5^{\circ} \mathrm{C}$ during November and February. During Southwest Monsoon the wind flows from South to West. During summer, winds are Southwesterly. The direction of the winds varies during October and January. Thunder storm, Cyclones and depressions occur in November and December.

\section{Methods}

Extensive floristic exploration of coastal regions in Pondicherry was carried out in different seasons of the year 2015 - 2016. Field data including height, stem colour, internodes, leaves, inflorescence, odour and colour of vegetative and floral parts were recorded. The collected specimens were preserved or pressed immediately. Field plant collection and herbarium were prepared following customary method [17]. Plant specimen was identified with the help of local floras and perusal of literatures. Plants were enumerated along with a brief description, habit, habitat, and locality. Some plants were identified from Botanical Survey of India, southern circle, Coimbatore, Tamil Nadu. The cited specimens were deposited in Bharathi Herbarium, Department of Botany, Bharathiar University, Tamil Nadu.

\section{Taxonomic Description}

Herb, annual, tufted or branched with erect to ascending; roots fibrous, and at nodes; internodes green, with a line of cilia. Leaves linear - lanceolate $0.2 \times 0.5 \mathrm{~cm}$ length or wide ???, glabrous, cilia along margins, rotund at base, acute at apex. Inflorescence terminal and axillary, consisting of 1-2 (-3) opposite or pseudo-umbels, ascending cincinni; $3-4 \mathrm{~cm}$ long, peduncle 1-3 cm long; bracteolate amplexicaul, persistent. Flowers bisexual or male; pedicel 3-6 cm long. Sepals 3, free, ovate-elliptic, c. $4 \times 2 \mathrm{~mm}$ long, pale green with purple tinge apically. Petals 3 , free; lobes orbicular, c. 5 $\times 8 \mathrm{~mm}$ long, pale lavender with dark contrasting veins, crenulate at margin, glabrous. Stamens 3, antesepalous; filament dorsifixed, free, c. $3 \mathrm{~mm}$ long, hairs purple-lavender, minutely appressed, bending away from the style in bisexual flower; anthers elliptic to oblong, deep blue-black, connective white-blue, dehiscence longitudinal; pollen white, ovate in shape (Fig. 1).

Flowering and Fruiting: October - January

Ecological notes: This species is commonly found in coastal areas, it grows in association with Dactyloctenium aegypticum, found in psammophytic condition.

Distribution: Sri Lanka, India (Tamil Nadu, now collected and reported from Pondicherry).

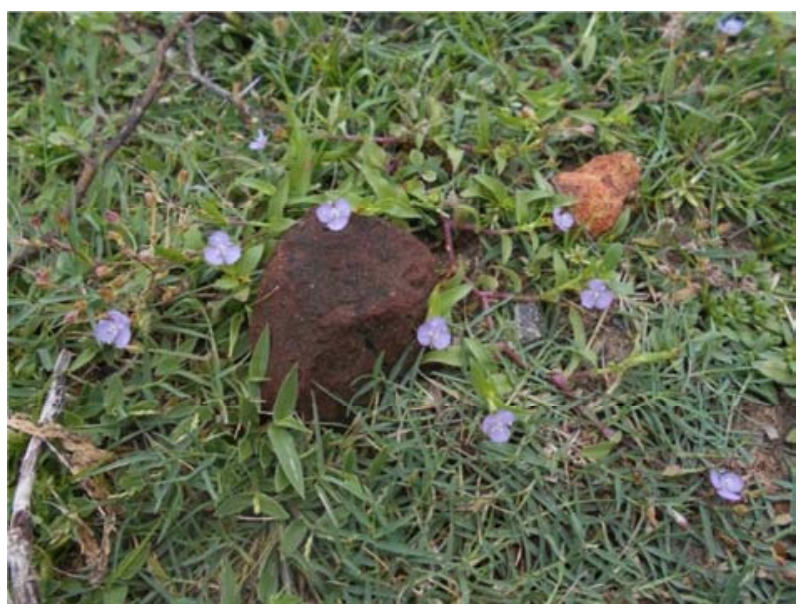

Figure 1. Natural habit of Murdannia striatipetala Faen.

\section{Conclusion}

The species is recently reported from the different states of India as the plant growing in wild from Tamil Nadu. The present observation of the species in wild state at different locations of Karaikal, Pondicherry state, further confirms the wide distribution of the species in India. At the present locations the species is found in scattered populations of a few individuals on coastal areas. In this appreciated plant was not cited in the previous floras of Pondicherry and the species is found growing in wild habitat in the present study area.

\section{Acknowledgement}

The authors are grateful to the Professor and Head, Department of Botany, Bharathiar University, for providing necessary facilities and useful guidance to carry out the study. We are also thankful to Head of Office, Botanical Survey of India, Southern Region, Coimbatore, Tamil Nadu for confirming the identity of the species and expert comments on the previous version of the manuscript which improved its quality.

\section{References}

[1] Arthur Cronquist, 1982. An integrated System of Classification of Flowering Plants. Vol. 34. Springer, New York Botanical Garden Press.

[2] Faden, R. B. 1998 CommelinaceaeIn: Kubitzki, K.(Ed.): The families and genera of vascular plants, Vol. 4. Springer Verlag, Berlin, pp. 109-128.

[3] Faden, R. B. 2001. New Taxa of Murdannia (Commelinaceae) from Sri Lanka, Novon. 11: 22-30.

[4] Linnaeus, C. 1753. Species Plantarum. Laurentii salvii, Stockholm..

[5] Mabberley, D. J. 2008. Mabberley's plant book. $3^{\text {rd }}$ Edition. U.K. Cambridge University Press.

[6] Hooker, J. D.1892. Flora of British India. Vol. 6. L. Reev \& Co., London, pp. 368-374. 
[7] Cooke, T. 1907. Flora of the Presidency of Bombay. Vol. 2. Taylor \& Francis, London, pp. 779-797.

[8] Fischer, C. E. C. 1932. Commelinaceae. In: J. S. Gamble (ed.), Flora of the Presidency of Madras. Vol. 3. Adlard \& Son, Ltd., London, pp. 1533-1552.

[9] Karthikeyan, S. 2000. A statistical analysis of flowering plants of India. In: Singh NP et al., editors. Flora of India. Introductory volume Part II: 201-217. Calcutta: Botanical Survey of India.

[10] Nandikar, M. D. 2013. A taxonomic revision of Indian spiderworts $\mathrm{Ph}$. D Unpublished Thesis. Kolhapur, India: Department of Botany, Shivaji University.

[11] Anna Ancy Antony, A. 2013. Taxonomic revision of the genus Murdannia Royle (Commelinaceae) in India. Published Thesis. Mahatma Gandhi University, Kottayam, India.

[12] Faden, R. B. 2000. Commelinaceae In: Dassanayke, M. D. \& W. D. Clayton (Eds): Revised Handbook Flora of Ceylon, Vol.14. A. A. Balman Rotterdam, pp. 116-196.
[13] Nandikar, M. D., and Rajan V. Gurav. 2015. Commelina badamica (Commelinaceae), a new species in India, Telopea. Vol.8: 513- 518.

[14] Rahul, B. Kamblea, Subhash Somkuwarb, Alka Chaturvedia, Shrikant Gundc and Mayur Nandikar. 2016. A new species of Murdannia Royle (Commelinaceae) from Chandrapur (Maharashtra State), India. Webbia: J. Pl. Tax. Geo. 1-4.

[15] Nandikar, M. D., Rajan V. Gurav and Divya umesh, 2011. Rediscovery of Murdannia striatipetala, a little known species from Southern India with a note on its identity and distribution. J. Bom. Nat. Hist. Soc.108: 1-201.

[16] Sambandan, K., Dhatchanamoorthy, N. and Jagadeesan, J. 2015. E-flora of Karaikal District, U. T of Puducherry, India. Online edition access at http://www.eflorakkl.

[17] Jain, S. K. and Rao, R. R. 1977. A handbook of field and herbarium method, today and tomorrows. Printers and publisher New Delhi, India. 